\title{
In the Castle of My Disease: an In-depth Study of Lorde Audre's The Cancer Journals
}

\author{
Rakhi Gupta ${ }^{1} \&$ Richa Arora $^{2}$ \\ ${ }^{1}$ Research Scholar, Department of Humanities and Social Sciences, Manipal University \\ Jaipur. \\ ${ }^{2}$ Professor $\mathcal{E}$ Head, Department of Humanities and Social Sciences, Manipal University \\ Jaipur. Email: Richa.arora@jaipur.manipal.edu
}

\begin{abstract}
The present study is an attempt to explore a mysterious voice: a voice which has been covered by multiple layers of darkness with excruciating pain, (the voice) which is fighting not for freedom but at least for a hope to live a common life again. Lord Audre, an African-American feminist writer and civil right activist, described her journey of breast cancer from the stage of 'diagnosed to recovery' and made her internal struggle visible to the reader by using the genre of interior monologue (William James) and 'Confessionalism' (Robert Lowell's Life Studies) which help to reveal her thought process or internal experiences clearly about her struggle throughout her journey. Therefore, this paper aims to tell the story of a determinate black African-American woman who is suffering not only from identity crisis or trapped in the world of homophobia but also struggled from cancer and is ready to reveal her personal account that is packed with heart-wrenching pain, grief, anguish, strength, perseverance, and the importance of maintaining self-identity even in the face of grave adversity.
\end{abstract}

Keywords: Confessional Writing, Enlightenment, Stream of Consciousness, Memory, Phobic Disorder

\section{Introduction}

I write for those women who do not speak, for those who do not have a voice because they were so terrified because we are taught to respect fear more than ourselves. We've been taught that silence would save us, but it won't. - (Lorde o3)

Audre Geraldine Lorde who has also written some work under the pseudonym, Rey Domini, is an American poet, essayist, autobiographer, and nonfiction writer. She is also famously known as a black lesbian feminist, mother, lover and a great renaissance poet. Audre has majorly raised the concept of 'voice' which, according to her, makes us unique because through writing, imaginary creation, or the power of word an author becomes able to convey his/her viewpoint, thoughts, emotion, and a hidden information to a reader by using the technical written weapons like, memoir, stream of consciousness, symbolism. Audre's works always focus on the theme of intersectional feminism (nonwhite, non-heterosexual), intimate relationship between two women, and a firm relationship with self-disease, self-reliance or self-world structure, transcendentalism, and human 's double consciousness. In brief, her works prove the major place of the Afro-American presence in American literature, their unspeakable desire, and deep psychic

(c) AesthetixMS 2019. This Open Access article is published under a Creative Commons Attribution Non-Commercial 4.0 International License (http://creativecommons.org/licenses/by-nc/4.o/), which permits non-commercial re-use, distribution, and reproduction in any medium, provided the original work is properly cited. For citation use the DOI. For commercial re-use, please contact editor@rupkatha.com. 
realities of the colored women's harsh experience of survival. Thus, her works majorly focus on the theme of female subjectivity, female language, and female literary career and through this they make an attempt to construct a female framework for a transparent mirror image of a woman (inside-outside) with a deep re-analysis of 'woman literature' (Walker 41). The Cancer Journal (1980) may be counted as one of the well-known gynocritics' (woman as a writer) work which not only replaces the male models of literary creation but also evaluates the unexplored concepts related to female experiences or hidden image of woman by the author, Audre Lorde. The Cancer Journals accepts and follows the rule of Virginia Woolf who believes that in order to reveal suppressed voice woman should 'kill the aesthetic ideal' as an 'Angel' (Woolf 12). The Cancer Journal is a real story of Audre Lorde herself. Life gave her two enormous challenges on her way: her identity crisis (because of her many sexual and romantic relationships with women) and subsequent battle with cancer. Audre's works depict a constant fight from the stereotypical society, and defiantly embraces and gilds what her society deems evil and opposite to nature. Lesbian sexuality and self-disclosure are central themes in Audre's work. Audre's journey of selfdiscovery encourages the idea of education of black women with the motivation of rising their black consciousness so that they can raise themselves from the dark veil of 'double consciousness'- sense of always looking at one's self through the eyes of others (Du Bois 132). Through Cancer Journals, she has not only provided the voice of race, class, or gender issues but also talked about the process of woman's psycho-dynamic states by uncovering her struggled journey towards sexual orientation or sexually identity crisis at a stage when she was unable to understand her sexual attraction towards the same gender or her feelings and frustration with her relationship and erotic desire with/to other women. Along with this, she has also openly talked about her continuous struggle and fear with the death and her acceptance of the natural process of life. In this way, she has presented death as a powerless figure by guiding her community in the right direction and tried to serve her community by hiding a tsunami of horrible emotion or helpless situations. Her denial for breast prosthesis, giving full value to her disability and considering it as an integral part of her identity and pride rather than a shameful, disgust or embarrassing one gives a greatly inspiring and enlightened example not only for her reader but for all those patients who are also suffering from the same fatal disease.

\section{Black Gynocriticism:}

Audre described her struggle as 'Anxiety of Authorship' (Gubar 51), especially when 'she is black, not thin' confronting the circumstances of castration from the authority and a continuous social control over her not only by white community but by black male community too who has respectful eye for either 'light color and thin woman' or 'white-colored woman'. Thus, through her work, Audre has urged all black women to forge self- definition of self-reliance that can only be possible if they will possess independence, bold, enterprising, fearless and undaunted spirit. For achieving such spirit, one must understand the value of education and turn one's (African American woman) attention to knowledge and should give oneself enough space for improvement as it has been perfectly said, "Knowledge is power" (Bacon 41). It has been followed by many great writers who have openly expressed their innermost feelings and uncovered their adventurous desire to choose the path that has not yet been taken because of fear, and that will make all the differences between them and others. Thus, Audre's works majorly aim to 'follow her heart' which can be imagined privately in society. It is rightly said, "There is no time for despair, no place for self-pity, no need for silence, no room for fear; we speak, we write, we do express through language" (Morrison 21). Henceforth, Audre's writings have the enlightened spirit for the invisible 
voice; her works fulfill the aim to break down the established boundaries and stereotype of black community that was cultivated under colonial rules. As she has stated in The Cancer Journals, "My silence had not protected me, your silence will not protect you", she has become an eternal voice for the invisible voice and the future generation because 'there is no time for despair, no place for self-pity, no need for silence as there is no room for fear'(Morrison 21).

\section{The Process of the Healing of the fragmented soul}

The paper is about a journey from a mental disorder to a physical disorder. Black women's autobiographies are grounded in the experience of physical and emotional slavery. Their writings spread the negative consequences of slavery, racial discrimination, and the patriarchal triple effect on colored women (Thrice oppression of colored women: class, gender, and race). It can rightfully be said that this paper is about a black lesbian woman's journey, her past experience of being lesbian and accepting her sense of eroticism proudly. In her works, Audre Lorde has used both her soul (autobiographical work, stream of consciousness, memoir) and theories (which metaphorically stand for the analytical study of mind) to make it not only interesting but also a lifetime teaching to all the readers who also suffer from the same problems (breast cancer and social phobia because of her (Audre Lorde) experience as an lesbian). Her works clearly describe how one feels when there is an inherent confliction between the self and the body, self is split from the body, or body and self still try to be united and make a hope for living a life with full of joy by trying to avoid conformity and false consistency, and that, according to Audre, can be possible only when she'll follow her own instinct and ideas (Emerson 21). Therefore, after reading her work one can say affirmatively say that Audre's writing is an impulse towards wholeness; what she says and how she says engage readers both emotionally and intellectually. She writes very particularly who she is: black woman, 'lesbian, feminist, a mother of two children, a daughter of Grenadian immigrants, educator, cancer survivor, and activist' (Audre 278). She creates material from her daily life.

At the time of living in a heterosexual world and accepting the harsh experience of invisible existence just because of having a different color (realities of Blackness) and different choices (lesbianism/homo-eroticism), only self-love can play the role of a big weapon against the patriarchal, binary, pre-conceived, and stereotyped society. Self-voice is always hidden and in this work, Audre is trying to find and listen to those voices because those voices make her 'different and subvert logocentrism' (Derrida 251). Therefore, Audre has taken on the task of disrupting the entire stream of metaphysical thought predicated on oppositions by elaborating and accepting deconstruction theory, and by applying it in real life by challenging the idea of a 'frozen structure and advances the notion that there is no structure or centre, no univocal meaning.' (Derrida 240)

"The Transformation of Silence into Language and Action" depicts Audre's mind stage which is grappling with a possible diagnosis of cancer in her famous and deep sight non-fiction, The Cancer Journal in which she has openly shown her frightening phase of life because her heart somehow knew that this silent pain could not protect her. Thus, this work, The Cancer Journal can also be known as a confessional work in which the writer is focusing on extreme moments of individual experience, the psyche, the personal trauma, and all the matters which form social taboos like thinking about suicide as natural. Mental disorder is a common disease from which each human is suffering in today's busy life, but not ready to reveal it as s/he sometimes her/himself is unaware with this unconscious anxiety or the suppressing of id because of the caged world named as superego (Freud 504). Hence, we, as readers, may find Audre's great achievement in her ability to transform her personal experience into art without losing its 
nightmarish immediacy. She depicted her depiction of intense painful imagery and a successful and a crystal clear portrayal of her inner emotional world while she was undergoing from the near-death experience.

By using the first person narrative mode, Audre Lorde has expressed successfully her mental thoughts or inner voice, emotions and mental disorders such as depression, stress directly to her readers. Hence, The Cancer Journals (1980) can be listed as one of the finest monologues by Audre Lorde, where she has made an attempt to present multitudinous thoughts and feelings which pass through her mind. Therefore, The Cancer Journals (1980) intimately details the author's profound struggle after being diagnosed with breast cancer and how her illness directly informed her identity as a lesbian African-American feminist advocating for civil rights. In a mixture of memoirs, journal entries, personal accounts, and poetic prose, Lorde has articulated how the female body is to be perceived in the wake of post-surgical alteration and how she, in this stage, became the victim of events over which she didn't have any control. But, she was not a passive victim who would accept herself as 'ugly', just because of the pre-conceived gaze of the society around her, who believed that being white was the only beauty. But, Audre is not worried about the society's views but about her close one's perspective for a big transformation in her body while grappling with her own radical mastectomy. As Audre has mentioned in her work, The Cancer Journals (1980) - "My primary concerns two days after mastectomy were hardly about what man I could capture in the future, whether or not my old boyfriend would still find me attractive enough, and even less about whether my two children would be embarrassed by me around their friends" (32), she shows her love for family, friends and her disregard for the disapproval of society which is full of prejudices, contempt thoughts for colored people or woman, and foolish consistency. It also portrays her believe in new American thought (transcendentalism) or in 'Trust Thyself (Emerson 201 ) which follows Emerson's well-known ideology, "That is true in your private heart is true for all men", and shows her anger towards the binary society, white community and their hostile behavior of discrimination ,violence, and their believe in 'Orientalism' (Said,1978) where the West (Occident) could control and authorize on the East (orient) because of their fake belief on 'cultural hegemony' (Gramsci 102) where so-called superior classes manipulate their imposed ruling culture on all and transform it into universally valid dominant ideology. She emphasizes following one's own voice rather than an intermediary, and, in her case the meaning of intermediary is conforming to social expectations. Thus, Audre, in The Cancer Journals, shows her new thought based on individuality, 'I Think, Therefore I Am' (51) where knowledge is based on experience derived from the senses. Henceforth, she embraced the formation of the new ideas continuously, rather than following innate ideas or traditions. Therefore, her work is listed as one of the most dynamic and most progressive conceptions. Furthermore, Lorde laments how society and the profit-driven medical industry have foisted an image of beauty on cancer-stricken women, and voices the need for it to change from the metaphorical journey of Heart of Darkness (Conrad 1899) to the heart of light. Above all, The Cancer Journals is all about heart-wrenching account of pain, anguish, grief, strength, perseverance, and the importance of maintaining identity in the mid of all grave adversity.

\section{Psycho-Analytical Perspective in The Cancer Journal}

Audre's work is about exploring a link between language and the unconsciousness. The Cancer Journals invents a whole new concept based on the realism of life. The Cancer Journals is about Audre's favorite territory, which can be called id (Freud 85). The id is human being's hidden desire, anxiety, and fear and it is revealed or expressed by gesture, sounds, facial expression, 
painting, and writing. But, Audre's has used writing as a weapon to subdue her repressed desire or internal train of thought. Audre has presented her love for the same sex and accepted her body proud fully even after suffering from prosthesis (amputation of one breast); she has tried to make woman-phobic world more comfortable. She accepts her one breast body when she affirmatively says, "women with mastectomies must become visible to each other" (35). As the hospital nurse (nurse) tried to remind her about the moral of office by saying "You will feel so much better with it on... And besides, we really like you to wear something, at least when you come in. Otherwise it's bad for the morale of the office" (Lorde 34), Audre replied bravely to her, "I cannot wear prosthesis right now because it feels like a lie more than merely a costume, and I have already placed this, my body under threat, seeking new ways of strength and trying to find the courage to tell the truth" (Lorde 35). With such great words, she manifested to the world or her readers that silence and invisibility go hand in hand with powerlessness and, thus, one should always raise their voice against any injustice or infringement. In this way, Audre, through her female framework, has expressed her ideas and given them a new direction which might be known as 'Towards a Black Feminist Criticism' (Smith 1977) because The Cancer Journal is the metaphorical hidden and struggling voice of all black lesbian women or the minor community. Thus, Audre's works belong to the African American canonical literature of the Nineteenth Century for attempting to change the social perspectives by deconstructing what Robert Patterson describes as 'the hierarchies of oppression' (9o), and to re-define it with the power of the voice of the silence women and inspire the future African American writers for their well-known works such as Alice Walker's The Third Life of Grange Copeland (1970), Toni Morrison's The Bluest Eye (1970), Maya Angelou's I Know Why the Caged Bird Sings (1969), and Toni Cade Bambara's The Black Woman: An Anthology (1970).

The aim of the study is to raise the concept of health awareness which always leads humans to success. Audre, through her work, stresses the maintenance of health with the acceptance of the problems related to body and tries to resolve the issues. As Audre says in her work, The Cancer Journal, "Women need to face the possibility and the actuality of breast cancer as a reality rather than as myth, or retribution, or terror in the night or a bad dream that will disappear if ignored" (35). Simultaneously, they need to be aware of the possibility of bilateral recurrence with vigilance rather than terror. Women must have a deep relationship with their bodies. She should be aware of the evolution of the body. And this can be possible if she is mentally strong, as Audre says, "women need to face the possibility and the actuality of breast cancer as a reality rather than as myth, or retribution, or terror in the night, or a bad dream that will disappear if ignored" (The Cancer Journals 32). Therefore, mental health of women is as important as physical health. The mind should also be peaceful and should be kept away from the illusion of worldly preconceived thoughts and enjoy the beauty of the world and the creation of God. Otherwise, they will find themselves in the stage of hallucination or schizophrenia. It is the stage of horror or ultimate darkness as if there is no hope for living anymore because no enthusiasm is left for life. In science, it is known as psychotic disorder which can be caused by many reasons like the social disadvantages, distressing events, repressed desire, a full of bitter past memories. Its outcome directly attacks the mind and causes many mental illnesses. Even, one of the well-known American Humanist Psychologist, Carl Roger also agreed with the ideology of self-awakening, as he stated in his work, Freedom to Learn (1969), ". . . for a person to grow mentally, they need an environment that provides them with genuineness (openness and self-disclosure), acceptance (without being seen with unconditional positive regards) and empathy- being listened to and understood)" (65). Audre, in The Cancer Journals, repetitively uses following sentence "I most regretted were my silences" (12). This shows her continuous battle with silence- a silence which is 
hiding her from 'real self, where human is not getting enough environment for knowing selfpotential or self-esteem and, as a result, suffers from the concept of identity crisis. Audre's voice went beyond the standard of social norms of the time when she transformed her voice into language and fought against her traumatic experience of self-alienation (her fight with lesbianism/ identity crisis), social alienation (her color became the reason of racism or discrimination), loneliness, and her anxiety and depression of losing the most attractive part of the body after catching the dangerous disease of breast cancer in the world where the white beauty always glorifies and physical appearance is considered more powerful than the inner beauty. Where in the name of appearance or external pressure, Audre is forced to wear a false breast which does not even work like artificial limbs whose function is to manipulate or to walk or denture, or that allow humans to chew their food. But, artificial breast doesn't do any function besides fulfilling the social stereotypes concerning with appearance. Henceforth, Audre challenges to the concept of beauty as a cultural aspect and the stubborn attitude toward the necessity for prostheses after breast surgery as if woman is programmed for her body only. Then she attacks the media which is the major way to sell a woman as an object, and which promotes the concept of external beauty by portraying woman's image as decorative machine for the use of consumer or for fulfilling male demand whereas one-breast woman is considered as a depraved, or at best, bizarre, a threat to 'morale'. Hence, there should be an acceptance for self, or love for self-body, if it is paralyzed, because it is 'your'; if not, it will lead to another discrimination which will be known as body-discrimination, "where woman is forced to choose between her life and her femininity" (40).

\section{Auotopathography: A Clear Depiction of Anguished Voice}

How society considers the importance of implantation during breast cancer and how an artificial breast is more important than saving a life of a human from cancer is hinted clearly as the doctor says, "it is better to die, if he /she is out from the concept of Performativity" (Butler 103). It is portrayed perfectly when a doctor says during operation in The Cancer Journal, "a woman may well be more likely to die from another cancer, but without that implant, she should not think of survival because, according to doctor- Breast is the sign of feminine beauty" (40). Audre's emphasizing for not wearing silicon breast and wants to break 'the repetition of action' (Butler, 36) shows her continuous fight with unconscious cognition (Sigmund Freud) or a storehouse of society's pre-fixed thoughts and notions. Therefore, when one fights for a desire of tabula rasa, it means an individual is trying to reach in the stage of self-actualization or to find the difference between real self and 'Ideal -self' (Roger 102): "I am a post-mastectomy woman who believes our feelings need voice in order to be recognized, respected, and of use.” (Audre o6)

The first chapter's title of The Cancer Journals itself defines that the eternal aim of the autopathography is the transformation of the silence and the invisibility of pain for repressed desire expressed into language and action. Hence, The Cancer Journal describes the author's physical and psychological struggle and tries to find her voice and turn it into poetry and writings to express the innermost desire and the physical and mental health of a colored woman during the nineteenth century and to use her writing as a weapon to explore black women's dilemma between society's expectation from individual and individual's hidden desire. The writing highlights many issues like the lack of life outside of the home, oppressive forces of the society who consider black color as 'inferior' or white as 'superior' and portrays the narrator's insanity as a way to protest the medical, the professional and the societal oppression of African-American women at the time. Hence, Audre's works challenge the social construction in the medical world 
and renew the image of the silent, powerless and passive black women and bring a new concept in the society named as utopian feminist which accepts the unorthodox concepts and lifestyle not only by declining artificial breast but also by accepting her real identity as homosexual.

Audre is the first and foremost black writer who first explored the concept of Homeostasis system in human body, which plays also a central role in her life as she spoke openly about the forbidden topics such as 'female masturbation' which is a source of her only internal pleasure during her physical disease time as she explores her experience of masturbation in The Cancer Journals, "The flame was dim and flickering, but it was a welcome relief to the long coldness" (15). And further she courageously describes the importance of it by declaring a woman's internal desire and by exposing female sexuality or same-sex desire or romantic friendship between two women into writing: "We are not to be allowed to define our needs nor our feelings nor our lives" (15). Thus, her writing not only becomes the part of autopathography but also raises many important issues, and the major issue is the development of homosexual identity or her dubious stage regarding her sexual orientation. Thus The Cancer Journals is also about her journey from self-alienation to selfacknowledgement. The other major issue of struggle is her loss of one major part of her body as she explains her crucial experience when doctor removed the whole portion of breast that contains cancer by applying mastectomy technique. Though such painful experience will always remain obscure she tries to reveal it from her writing as she says in her work The Cancer Journals"I must let this pain flow through me and pass on. If I resist or try to stop it, it will detonate inside me, shatter me, and splatter my pieces against every wall and person that I touch." (o7) Thus writing or literature becomes her weapon to reveal her Id (unconscious state of mind) or her primary source of instinctual force. She further explains the reason for her openness towards the public, "I have come to believe over and over again that what is most important to me must be spoken, made verbal and shared, even at the risk of having it bruised or misunderstood. That the speaking profits me." (12)

Audre Lorde's condition can be compared with the unknown character of The Yellow Wallpaper. Audre's life also revolves around the wallpaper of disease and a continuous confrontation with a cultural hegemonic society where power and knowledge go together and ruling class manipulate the culture, perceptions, and beliefs of the society according to their suitability and generate the concept of binary opposition where one is always considered as other or inferior. Thus, Audre's writing becomes her only source of power to prevent her from the psyche horror or mental insanity as she is not alone with her fight; she has family just like Claudia MacTeer and Frieda MacTeer (character in The Bluest Eye-1980) who have the ability to survive in an inverted world because they know their inner worth as well as inner violence from the injustice provided by the society and the black community's idealization of the white beauty standard. Because she is only the victim of the racism, not of the harshness of her family, her end cannot be expected like Pecola who has become invisible to others because of their (society's and even family's) continuous hatred eyes of ignorance. Audre didn't face the same consequences that Pecola has suffered in turning herself completely into a madwoman. But, Audre showed a hopeful ending and becomes the inspiration source for all future generations by becoming like Janni Crawford (the main protagonist in Their Eyes were Watching God) who put her finger on the trigger of her own destiny. (Hurston 14)

\section{A Travesty of Self-Identity: Trapped from the Concept of Intersectionality}

The Concept of Intersectionality has been brought by Kimberlé Crenshaw for the voice of invisible women, especially in learning new literature with the lens of black lesbian writer. The Cancer 
Journals' second chapter, "A Black Lesbian Feminist Experience” portrays a vivid picture of a black woman who is trapped with the interlocking system of power impact on those who are most marginalized in society. As Audre Lorde says in her famous work, Sister Outsider (1984), "Those of us who are poor, who are lesbian, who are black, who are older, always stand outside the circle of this society's definition of acceptable women" (104). Through the lens of personal journal Audre deals with the evolution of Lorde's sexuality and self-awareness. Simultaneously, she also discusses the importance of speaking and encourages others to raise their voice against the all kinds of injustice (how black women have been viewed critically by the outsiders) and their (African American women's) hidden and painful voice through writing that will protect them from their continuous experienced as marginalized and oppressed despite their fear in respect of not speaking. Audre, thus, further introduces the concept of dualism or double consciousness $(\mathrm{Du}$ Bois) in her work The Cancer Journals which further leads to the concept of identity crisis. When a human faces identity-related problems, he/she tries to keep himself away from normal life. It prevents his/her internal and external development, and, as a consequence, an individual finds struggle to identify her relationship with society and against the homophobic religious doctrine. Thus, Audre not only accepted love strongly of the same gender but also became one of the first black woman writers who refused to be delineated by male establishment of the models of femininity and dealt positively and openly about her sexuality as an accepted part of own identity. Thus, Audre Lorde not only comes out from her comfort zone by using the tool of confessionalism and reveals the darker secrets bravely to the stereotypical society and removes the taboos associated with black lesbian and conveys it through her writings as natural as heterosexual orientalism but also she frees herself from the inexorable structure of patriarchy through her action.

\section{Conclusion:}

The aim of the study is to show to the society about the fake views on women which leave them to suffer eternally: the superficially erotic has been encouraged as a sign of female inferiority, women have been made to suffer and to feel both contemptible and suspect by virtue of its existence, rather accepting it as natural and a source of human body's inner satisfaction. By accepting the concept of self-authorization, Lorde Audre avoids the conformity and false consistency made by the chain of being or hierarchical structure of society and did what she thinks is right, no matter what others think. Hence, her writing proposes the concept of 'SelfReliance' (Emerson) and followed Emerson's concept of 'Transcendentalism' which beliefs that reliance upon institutionalized religion hinders the ability to grow mentally as an individual. Her writing is the powerful expression of her inner world, her continuous struggle with cancer and amputation of the body part, the uncertainty with life, her struggle with insomnia, taking medication at night to induce sleep, and frequently waking up early. Her works deal with the theme of death, immortality. Thus, her writing is all about her strength which realistically deals with the most melancholic situations. Audre Lorde's The Cancer Journal is not only about her struggle with breast cancer but also about her fight with her identity as during her time homosexuality was considered a criminal offence. Her aim was to declare homosexual desire with liberal mind and their fundamental right of living a life as equal as any heterosexual is living and to come out from the dilemma of double consciousness- in which a person's sense of identity becomes typically insecure due to a change in their expected aims or role in society. Audre's work rejects the ideal form of literature and shows the bitter reality of life and also inverts the 
traditional stereotypes of the 'heroine' who is beautiful, slim, or, in Virginia Woolf words, 'kill the aesthetic ideal'(22), and reveals the real experience of life in the words of Lorde Audre.

\section{References}

\section{Primary Source}

Lorde, Audre. 2006. The Cancer Journals: Special Edition. San Francisco: Aunt Lute Books.

\section{Secondary Sources}

Butler, Judith. 20o1. "Gender Trouble." The Norton Anthology of Theory and Criticism. Ed.Vincent B. Leitch. 2nd ed. New York: W.W. Norton \&amp; Company, Inc. 2536-53.

Cixous, Hélène. 2001. "The Laugh of the Medusa." The Norton Anthology of Theory and Criticism. Ed. 2. Leitch, Vincent B. New York: W.W. Norton \&amp; Company, Inc.

Descartes, R. 1998. Discourse on Method and Meditations on First Philosophy. 4th ed. Indianapolis: Hackett Pub.

Du Bois, W.E.B. 1961. The Souls of Black Folk. Greenwich: Fawcett

Ellison, Ralph. 1995. Invisible Man. New York: Knopf Doubleday

Fanon, Frantz. 1963. The Wretched Of The Earth. New York: Grove Press

Fanon, Frantz. 1952. Black Skin White Mask. New York: Grove Press

Freud, Sigmund. 1989. Beyond the Pleasure Principle. Trans. James Strachey: New York

Morrison, Toni. 1991. The Bluest Eye. Vintage Publications New York

Saussure, Ferdinand et al. 1966. Course in General Linguistics. New York: McGraw-Hill

Showalter, Elaine. 2007. "Towards A Feminist Poetics", Contemporary Criticism, Ed. VS Seturaman, Macmillan, Chennai

Showalter, Elaine. 1977. A Literature of Their Own: British Women Novelist from Bronte to Lessing. N.J: Princeton University Press

Walker, Alice, 1944. 1989. In Search of Our Mothers' Gardens: Womanist Prose. San Diego: Harcourt Brace Jovanovich, 1983. Wollstone Craft, Mary. A Vindication of Rights of Women" in A Vindication of Rights of Women.London: London: J.M Dent and co. 